\title{
Modelling long-term changes in soil phosphorus and carbon under contrasting fertiliser and grazing management in New Zealand hill country
}

\author{
${ }^{1}$ Centro de Investigación Veterinaria de Tandil (CIVETAN), UNCPBA-CICPBA-CONICET, B7000GHG, Tandil, \\ Buenos Aires, Argentina. \\ 2 AgResearch Grasslands, Private Bag 11008, Palmerston North 4422, New Zealand. \\ Ronaldo.vibart@agresearch.co.nz
}

\begin{abstract}
Soil carbon $(\mathrm{C})$ stocks under permanent New Zealand pastures vary with slope and aspect due to differences in primary production, animal behaviour and nutrient return. An existing nutrient transfer model was extended using a web-based, general-purpose modelling tool to simulate long-term changes in soil phosphorus $(\mathrm{P})$ and $\mathrm{C}$ in hill country under contrasting fertiliser and sheep stocking regimes. Three self-contained farmlets were examined: no P applied; $125 \mathrm{~kg}$ single superphosphate (SSP)/ha/year; and $375 \mathrm{~kg} \mathrm{SSP/ha/year,} \mathrm{since} 1980$. The refined spatial model was able to simulate $\mathrm{P}$ and $\mathrm{C}$ distribution with varying slopes and aspects. For example, the mean annual changes in soil $\mathrm{P}$ and $\mathrm{C}$ were greater on low slopes and eastern aspects than on the other two slope and aspect positions, consistent with observed changes in these nutrients. However, the model overestimated changes in soil $\mathrm{C}$, which highlighted both gaps in current knowledge and key factors influencing change in soil C stocks. Understanding the spatial patterns of soil $\mathrm{C}$ across the landscape will be critical in the design of soil $\mathrm{C}$ monitoring regimes, should soil $\mathrm{C}$ stocks be considered at a national level as a sink or source of $\mathrm{CO}_{2}$ emissions.
\end{abstract}

Keywords: soil carbon, phosphorus fertiliser, sheep grazing, pasture production, nutrient transfer, animal behaviour.

\section{Introduction}

Pastoral hill country, covering 4.1 million hectares (https://beeflambnz.com/knowledge-hub/PDF/FS077hill-country-sheep-beef) is characterised by a wide variability in micro-topography, spatial differences in soil conditions, and pasture production potentials (Lambert et al. 2000). The disproportionate nutrient accumulation in low slopes and eastern or southern aspects with nutrient depletion in high slope areas and northern aspects can be attributed to multiple factors. These include animal behaviour, grazing management and differences in soil depth and development, as well as their influence on soil water content, incident solar radiation and biological processes, which in turn influence plant growth, species composition, litter return and excretal deposition (Lambert and Roberts 1978; López et al. 2003b). The associated improvement on soil structure, nutrient and water storage capacities caused by increasing amounts of soil carbon (C) content, has gained worldwide interest as a potential strategy to reduce $\mathrm{C}$ emissions (Lal et al. 2015). In New Zealand, several studies have reported different trends among medium- to long-term soil $\mathrm{C}$ stocks under grazing systems (Parfitt et al. 2014; Schipper et al. 2017; Mackay et al. 2018). A better understanding of the attributes of the landscape (i.e. slopes and aspects) and associated influence on livestock behaviour are essential both to assess soil $\mathrm{C}$ dynamics in these systems and for the development of strategies for monitoring soil C stocks.

Previous modelling efforts to capture long-term soil nutrient dynamics under hill country grazing in New Zealand have been reported (Saggar et al. 1990; Hoogendoorn et al. 2011). The model used in the current study was built based on the model of phosphorus (P) and sulphur (S) transfer by Saggar et al. (1990) and the simple C models by Hoogendoorn et al. (2011). Aspect was added to capture this critical spatial element as was increased soil depth (from 15 to $30 \mathrm{~cm}$ ) using data from a long-term $P$ and sheep-grazing experiment at the Ballantrae Hill Country Research Station. The aims of this study were to establish whether or not: (i) a longterm spatial nutrient budget model could be developed that captured the influence of both slope and aspect on the distribution and dynamics of $\mathrm{P}$ and $\mathrm{C}$ in hillcountry; and (ii) the spatial model could simulate the distribution of soil $\mathrm{P}$ and $\mathrm{C}$ in hill country as influenced by contrasting $\mathrm{P}$ fertiliser and sheep stocking regimes. Such a model would be valuable in exploring options for changing soil $\mathrm{P}$ and $\mathrm{C}$ sequestration rates and for designing spatially relevant sampling regimes.

\section{Materials and Methods}

Field location and topography

The Ballantrae Hill Country Research Station is located in southern Hawke's Bay (40¹8'S 175'50'E), 300 m.a.s.l. with mean long-term annual air temperature and rainfall of $12.8^{\circ} \mathrm{C}$ and $1270 \mathrm{~mm}$, respectively. The soils are classified as Andosols and Luvisols with a 
silt-loam texture (Lambert et al. 2000). The farmlets included in this study are part of a larger study described in Lambert et al. (2000). Three self-contained farmlets were examined (NF, LF, HF) that have been under different fertiliser and sheep grazing regimes since 1980: NF (9.7 ha): no single superphosphate (SSP) applied; LF (8.1 ha): $125 \mathrm{~kg} \mathrm{SSP} /$ halyear; HF (6.8 ha): $375 \mathrm{~kg} \mathrm{SSP} / \mathrm{ha} /$ year. Farmlets were stocked with sheep to maintain similar grazing pressure (i.e., stock units SU per unit pasture production); corresponding annual mean stocking rates were $6.0,10.6$, and $16.1 \mathrm{SU} / \mathrm{ha}$ $(1 \mathrm{SU}=550 \mathrm{~kg} \mathrm{DM})$.

Three categories of slope and aspect were used to describe the topography of the farmlets: Low (LS; $0-12^{\circ}$ ), Medium (MS; $13-25^{\circ}$ ) and High (HS; $>25^{\circ}$ ) slope on different aspects grouped relative to the true north as East $\left(\mathrm{E} ; 35-155^{\circ}\right)$, North West $(\mathrm{NW} ; 155$ $275^{\circ}$ ) and South West aspect (SW; 275-35 $)$ (Table 1).

\section{Modelling tool, background and model development}

The long-term spatial-nutrient budget model ( $\mathrm{P}$ and C) was built using the web-based, general-purpose simulation and modelling tool Insight Maker (FortmannRoe 2014). The primary modelling approaches selected to examine the impact of slope and aspect were taken from a P and S transfer model (Saggar et al. 1990) and the simple $\mathrm{C}$ and $\mathrm{N}$ cycling models of Hoogendoorn et al. (2011) that were parameterised mostly with New Zealand data. This approach recognises the inherent differences in a wide range of soil attributes and the influence of the topography on primary production and animal behaviour as well as how these affect the dynamics of the biogeochemical cycles of $\mathrm{P}$ and $\mathrm{C}$ soil stocks over time. The effect of aspect as it influences primary production (Lambert and Roberts 1978) and

Table 1 Land area (\%) in each slope and aspect combination within each farmlet. NF: no single superphosphate (SSP) applied; LF: $125 \mathrm{~kg} \mathrm{SSP/}$ ha'year; HF: 375 kg SSP/ha/year, since 1980.

\begin{tabular}{lcccc}
\hline \multirow{2}{*}{ Slope } & Aspect & \multicolumn{3}{c}{ Farmlet } \\
\cline { 3 - 5 } & & NF & LF & HF \\
\hline Land area (\%) & & & & \\
Low & $\mathrm{E}$ & 14 & 7 & 5 \\
& $\mathrm{SW}$ & 4 & 11 & 4 \\
& $\mathrm{NW}$ & 2 & 10 & 9 \\
Medium & $\mathrm{E}$ & 30 & 8 & 16 \\
& $\mathrm{SW}$ & 11 & 16 & 10 \\
& $\mathrm{NW}$ & 10 & 22 & 33 \\
High & $\mathrm{E}$ & 16 & 4 & 12 \\
& $\mathrm{SW}$ & 2 & 3 & 3 \\
& $\mathrm{NW}$ & 11 & 20 & 9 \\
\hline
\end{tabular}

animal behaviour including grazing, camping and nutrient return (López et al. 2003b), were added to the framework. Mackay and Costall (2016) reported that under high $\mathrm{P}$ fertiliser inputs, $\mathrm{P}$ was found at depths greater than $15 \mathrm{~cm}$ prompting extending the depth of modelling to $30 \mathrm{~cm}$, which is also more meaningful when exploring the changes in soil C stocks.

\section{Pasture production, pasture intake and utilisation} Long-term (1975-2015) pasture production (kg DM/ha/ year) for the three farmlets (NF, LF, HF) was simulated in response to a change in Olsen $\mathrm{P}$ values for the three slope categories using data published by Lambert et al. (2014). To represent this relationship, equations were developed with a triangular distribution fitted between the upper and lower limits estimated for the confidence intervals (95\%). According to Lambert et al. (1983), E aspect was the most productive aspect over the nine-year period from 1972/73 to $1980 / 81$ (9325, 9003 and $8388 \mathrm{~kg}$ DM per annum for E, NW and SW aspects, respectively).

The farmlets have been continuously grazed with breeding ewes since 1975. Since then, the stocking rate has fluctuated around 10.6 SU/ha on the LF and has been as high as $16 \mathrm{SU} /$ ha on the HF pasture (Mackay \& Costall 2016). Pasture intake ( Past $_{\text {int }}$, kg DM/ha/ year) was calculated assuming a $55-\mathrm{kg}$ ewe rearing one lamb consuming $550 \mathrm{~kg}$ DM intake per unit of sheep stocking unit per ha (Coop 1965). According to López et al. (2003a), low and medium slopes have a higher probability of defoliation than high slopes. In order to represent animal behaviour, the probability of pasture defoliation for low $\left(\mathrm{PD}_{\text {low }}\right)$, medium $\left(\mathrm{PD}_{\text {med }}\right)$ and high slope $\left(\mathrm{PD}_{\text {high }}\right)$ were assumed to be $0.48,0.30$ and 0.22 , respectively. To keep selective defoliation constant, the allocation of Past ${ }_{\text {int }}$ was linked to the composition of slope and aspect area per farmlet. Pasture utilisation (PU, \%) for each slope and aspect combination was calculated as the ratio between Past int $_{\text {and }}$ asture production weighted by percentage area.

\section{Spatial distribution of nutrients in animal excreta}

The approach outlined by Saggar et al. (2015) was applied to account for the effect of topography-driven spatial variability on nutrient excretion return from livestock. The areas for $\mathrm{E}$ and $\mathrm{NW}$ aspects were used to represent changes in excreta allocation and the corresponding slope equations were generated. Model parameters and equations used to calculate changes in total soil $\mathrm{P}$ and $\mathrm{C}$ content to a depth of $30 \mathrm{~cm}$ are outlined in Appendix 1 and 2, respectively.

\section{Results}

Phosphorus and carbon dynamics across farmlets Results from the model showed that $\mathrm{P}$ fertiliser and sheep stocking regime affected pasture production (8.3, 
9.7 and $12.7 \mathrm{t} \mathrm{DM/ha} \mathrm{for} \mathrm{NF,} \mathrm{LF} \mathrm{and} \mathrm{HF,} \mathrm{respectively)}$ and nutrient dynamics of both P (Table 2) and C (Table 3). Fertiliser represented $37 \%$ and $47 \%$ of $P$ inputs in LF and HF, respectively. Despite the higher amounts of $\mathrm{P}$ removed by animal products ( Past $_{\mathrm{P} \text { ap }}$ ) in $\mathrm{HF}$, this farmlet almost doubled and tripled the $\mathrm{P}$ recovered as plant litter (Plant $\left.\mathrm{P}_{\mathrm{Plitter}}\right)$ and dung $\left(\mathrm{P}_{\mathrm{exc}}\right)$ compared with LF and NF, respectively.

Although the highest amount of soil $\mathrm{C}$ allocated from roots and rhizodeposition $\left(\mathrm{C}_{\text {root and rhizodeposition }}\right)$ was observed in $\mathrm{HF}$, the proportion of $\mathrm{C}$ allocated to soils decreased as the $\mathrm{P}$ fertility and livestock carrying capacity was increased across the farmlets. The flux of $\mathrm{C}_{\text {root and }}$ rhizodeposition into the soil has shown to be the main source of soil C stocks $(69 \pm 3 \%$ ), followed by litter decomposition $\left(\mathrm{C}_{\text {litter }}, 24 \pm 5 \%\right)$ and $\mathrm{C}$ from dung $\left(\mathrm{C}_{\mathrm{exc}}, 7 \pm 2 \%\right)$. But with higher pasture production, the levels of $\mathrm{C}$ intake by the animals increased, leaving similar amounts of plant litter and $\mathrm{C}$ fluxes through plant and soil respiration $\left(\mathrm{C}_{\text {res- }}\right.$ ps), which showed an exponential behaviour (the latter accounts for $72-75 \%$ of total $C$ losses).

Overall across farmlets, while the model overestimated changes in soil $\mathrm{P}$ and $\mathrm{C}$ on $\mathrm{HF}$, it underestimated changes in soil P on NF (Figure 1). The performance of the model was evaluated using parameters derived from the comparison of observed and predicted values. The association between observed and predicted values was measured by the concordance correlation coefficient $\left(\mathrm{p}_{\mathrm{c}}\right.$; it evaluates the degree to which observed/predicted pairs fall on a 45-degree line, closer to 1 is better), the coefficient of determination $\left(\mathrm{R}^{2}\right.$; a measure of model precision $)$ and the bias correction factor $\left(\mathrm{C}_{\mathrm{b}}\right.$; it evaluates how far the best-fit line deviates from the 45-degree line, a measure of model accuracy). Overall, values of $\mathrm{p}_{\mathrm{c}}, \mathrm{R}^{2}$ and $\mathrm{C}_{\mathrm{b}}$ were 0.80 and $0.57,0.84$ and 0.64 , and 0.93 and 0.89 for soil $\mathrm{P}$ and $\mathrm{C}$, respectively.

\section{Soil phosphorus and carbon changes across slopes and aspects}

The net loss of $\mathrm{P}$ from the MS and HS positions and NW aspect (Figure 2) is most likely a consequence of the flow of $\mathrm{P}$ in animal dung from MS and HS to LS positions, and the amount of dung returned to the different aspects, respectively. The spatial distribution of $\mathrm{P}_{\mathrm{exc}}$ and $\mathrm{C}_{\mathrm{exc}}$ showed that $61 \%, 29 \%$ and $10 \%$ were deposited on LS, MS and HS positions with a similar pattern across the three farmlets. In terms of aspect positions, about $50 \%, 30 \%$ and $20 \%$ of $\mathrm{P}_{\text {exc }}$ and $\mathrm{C}_{\text {exc }}$ were returned on the E, SW and NW aspects in $\mathrm{HF}$ and LF farmlets, whereas LF received $75 \%$ of the dung on the $\mathrm{E}$ aspect ( $60 \%$ of the farmlet area).

Within the farmlets, the mean modelled annual changes in soil $\mathrm{C}$ were greater on the LS and $\mathrm{E}$ aspects than at the other two slope and aspect positions (Figure 2). The simulated pasture production at the different
Table 2 Modelled annual mean \pm standard deviation of phosphorus $(\mathrm{P})$ dynamics and $\mathrm{P}$ changes across the farmlets. NF: no single superphosphate (SSP) applied; LF: 125 kg SSP/ha/year; HF: 375 kg SSP/ ha/year, since 1980 .

\begin{tabular}{|c|c|c|c|}
\hline \multirow[b]{2}{*}{ Item (on a per year basis) } & \multicolumn{3}{|c|}{ Farmlet } \\
\hline & ) NF & LF & HF \\
\hline \multicolumn{4}{|l|}{ Inputs ${ }^{1}$} \\
\hline $\mathrm{P}$ fertiliser (kg P/ha) & 0.0 & 11.3 & 33.8 \\
\hline Plant $_{\mathrm{P} \text { litter }}(\mathrm{kg} \mathrm{P/ha})$ & $6.3 \pm 1.5$ & $8.4 \pm 2.7$ & $15.0 \pm 4.1$ \\
\hline$P_{\text {exc }}(\mathrm{kg} \mathrm{P} / \mathrm{ha})$ & $7.0 \pm 1.5$ & $10.8 \pm 2.1$ & $23.3 \pm 4.9$ \\
\hline \multicolumn{4}{|l|}{ Internal processes } \\
\hline Past $_{P \text { intake }}(\mathrm{kg} \mathrm{P/ha})$ & $8.3 \pm 1.7$ & $12.7 \pm 2.4$ & $27.5 \pm 5.7$ \\
\hline Past $_{\text {p rap }}(\mathrm{kg} \mathrm{P} / \mathrm{ha})$ & $1.2 \pm 0.3$ & $1.9 \pm 0.4$ & $4.1 \pm 0.9$ \\
\hline \multicolumn{4}{|l|}{ Outputs } \\
\hline Plant $_{\mathrm{P} \text { uptake }}(\mathrm{kg} \mathrm{P} / \mathrm{ha})$ & $14.5 \pm 0.5$ & $21.1 \pm 3.1$ & $42.4 \pm 7.4$ \\
\hline TPL (kg P/ha) & $1.3 \pm 0.0$ & $1.3 \pm 0.0$ & $1.4 \pm 0.0$ \\
\hline $\begin{array}{l}\text { Farmlet soil P change } \\
\text { (kg P/ha) }\end{array}$ & $-2.6 \pm 0.3$ & $+7.2 \pm 0.4$ & $+25.3 \pm 0.9$ \\
\hline
\end{tabular}

${ }^{1}$ See Appendix 1 for details on each input.

Table 3 Modelled annual mean \pm standard deviation of carbon (C) dynamics and $C$ changes across the farmlets. NF: no single superphosphate (SSP) applied; LF: 125 kg SSP/ha/year; HF: 375 kg SSP/ ha/year, since 1980 .

Farmlet

\begin{tabular}{llll}
\hline Item (on a per year basis) & NF & LF & HF \\
\hline
\end{tabular}

Inputs $^{1}$

$\mathrm{C}_{\text {root and rhizodeposition }}$

$\begin{array}{llll}\text { (t C/ha) } & 3.7 \pm 0.1 & 4.1 \pm 0.1 & 5.0 \pm 0.1 \\ \mathrm{C}_{\text {litter }}(\mathrm{t} \mathrm{C} / \mathrm{ha}) & 1.3 \pm 0.3 & 1.4 \pm 0.3 & 1.6 \pm 0.3 \\ \mathrm{C}_{\text {exc }}(\mathrm{t} \mathrm{C} / \mathrm{ha}) & 0.3 \pm 0.1 & 0.4 \pm 0.1 & 0.6 \pm 0.1\end{array}$

Internal processes

$\mathrm{C}_{\text {intake }}$ (t C/ha) $\quad 1.7 \pm 0.3 \quad 2.1 \pm 0.3 \quad 3.0 \pm 0.4$

Outputs

$\mathrm{C}_{\text {methane }}$ (t C/ha) $\quad 0.09 \pm 0.02 \quad 0.10 \pm 0.02 \quad 0.15 \pm 0.02$

$\mathrm{C}_{\text {res-a }}$ (t C/ha) $\quad 1.2 \pm 0.2 \quad 1.5 \pm 0.2 \quad 2.2 \pm 0.3$

$\begin{array}{llll}\mathrm{C}_{\text {ap }}(\mathrm{t} \mathrm{C} / \mathrm{ha}) & 0.03 \pm 0.01 & 0.04 \pm 0.01 & 0.06 \pm 0.01\end{array}$

$\mathrm{C}_{\text {res-ps }}$ (t C/ha) $\quad 4.9 \pm 0.05 \quad 5.2 \pm 0.1 \quad 6.5 \pm 0.2$

$\begin{array}{llll}\mathrm{POC}(\mathrm{t} \mathrm{C} / \mathrm{ha}) & 0.05 & 0.05 & 0.05\end{array}$

$\begin{array}{llll}\mathrm{DOC}(\mathrm{t} \mathrm{C} / \mathrm{ha}) & 0.23 & 0.17 & 0.12\end{array}$

Farmlet soil $\mathrm{C}$ change

$\begin{array}{llll}(\mathrm{t} \mathrm{C} / \mathrm{ha}) & +0.21 \pm 0.2 & +0.47 \pm 0.3 \quad+0.56 \pm 0.3\end{array}$

2 See Appendix 1 for details on each input. 

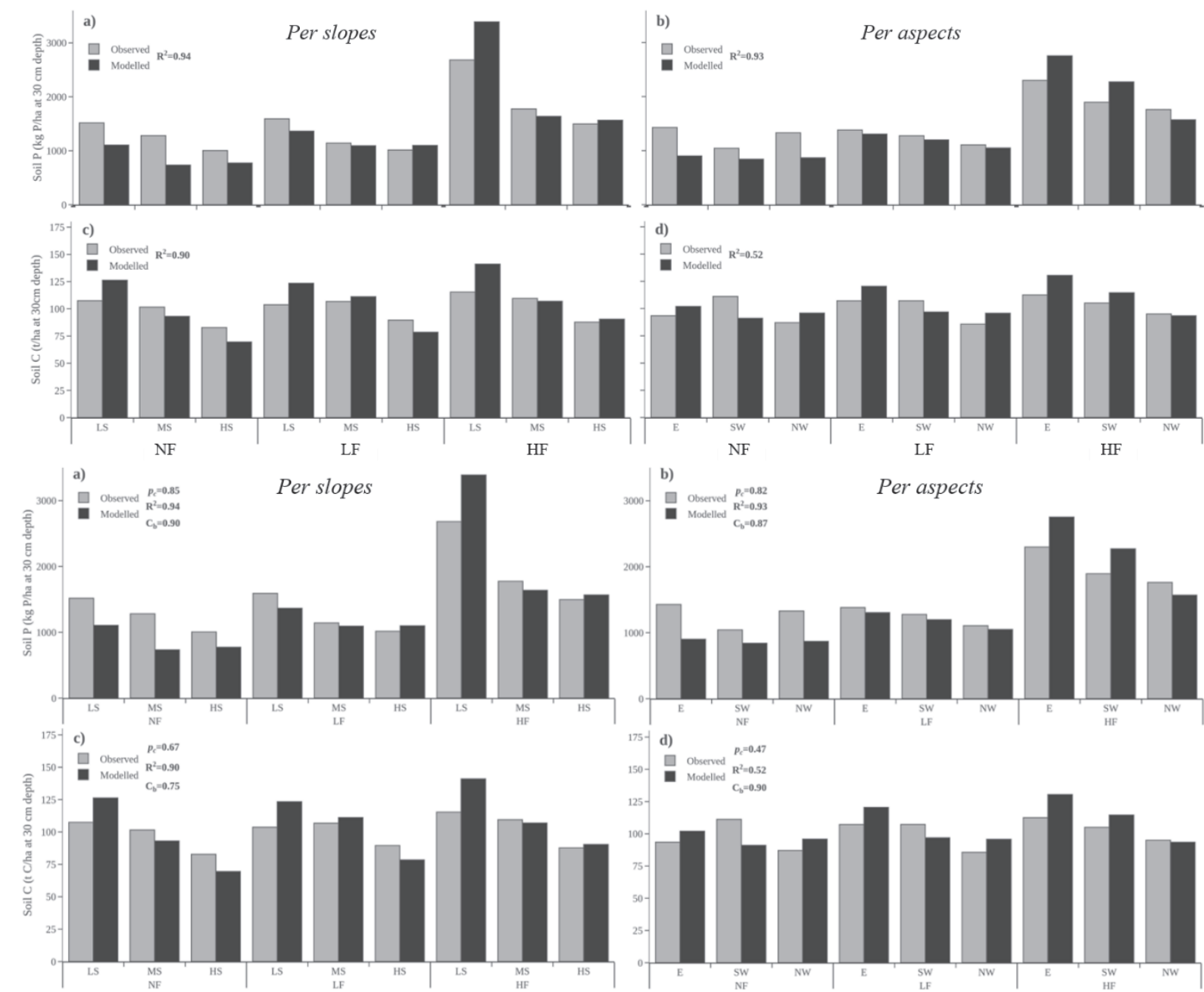

LF

HF

Per aspects

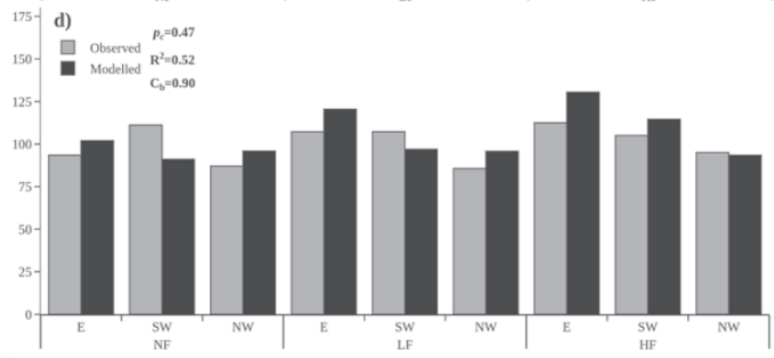

Figure 1 Soil $\mathrm{P}(\mathrm{a}$ and $\mathrm{b}$ ) and $\mathrm{C}(\mathrm{c}$ and d) stocks at 0-30 cm depth across the different farmlets [NF (no SSP applied); LF (125 $\mathrm{kg} \mathrm{SSP/ha/year);} \mathrm{HF} \mathrm{(375} \mathrm{kg} \mathrm{SSP/ha/year),} \mathrm{since} \mathrm{1980]} \mathrm{as} \mathrm{affected} \mathrm{by} \mathrm{slope} \mathrm{(LS} \mathrm{=} \mathrm{low} \mathrm{slope,} \mathrm{MS} \mathrm{=} \mathrm{medium} \mathrm{slope,}$ $\mathrm{HS}=$ high slope $)$ and aspect $(\mathrm{E}=$ east aspect, $\mathrm{SW}=$ southwest aspect, $\mathrm{NW}=$ northwest aspect) positions in 2003. pc: concordance correlation coefficient; $\mathrm{R}^{2}$ : coefficient of determination; $\mathrm{C}_{\mathrm{b}}$ : bias correction factor between observed and modelled data.

slope positions $(13.8 \pm 2,9.9 \pm 2$ and $7.6 \pm 2 \mathrm{t} \mathrm{DM} /$ ha for LS, MS and HS, respectively) resulted in higher partitioning and translocation of $\mathrm{C}$ to $\mathrm{C}_{\text {root and rhizodeposition }}$ at HS. Under LS and HS positions, $\mathrm{C}_{\text {res-ps }}$ was up to $25 \%$ higher and up to $23 \%$ lower, respectively, than the average obtained across the farmlets (Table 3 ). The $\mathrm{E}$ aspect had a large proportion of $\mathrm{C}$ that remained in the above ground component $\left(0.95-0.85 \mathrm{C}_{\text {shoot }} / \mathrm{C}_{\text {root }}\right.$ and rhizodeposition at $\mathrm{HF}$ and $\mathrm{LF})$ and $\mathrm{C}_{\text {res-ps }}(7-12 \%$ higher compared with NW and SW aspects).

\section{Discussion}

The design of the long-term $\mathrm{P}$ fertiliser and sheep grazing experiment meant that it was inherently unlikely that the distinct effects of $\mathrm{P}$ fertiliser application and sheep stocking rate on soil C stocks could be separated. Notwithstanding this limitation, the trial enabled an assessment of the interactions between livestock and topographic features (such as slope and aspect), their contribution to the cycling of nutrients and changes in soil nutrient stocks and enabled the inclusion of these features in the calculation of total $\mathrm{P}$ and $\mathrm{C}$ stock.

Results obtained from the model were a reasonable approximation of the amounts of $\mathrm{P}$ distributed across the landscape and the actual $\mathrm{P}$ dynamics in each of the three farmlets in terms of: i) the amounts of pasture (and P) consumed by the grazing animal; ii) the amount of ungrazed pasture and, therefore, $P$ returned in litter; iii) the amounts of dung deposited on the different slope and aspect combinations; and iv) the amount of P subsequently 


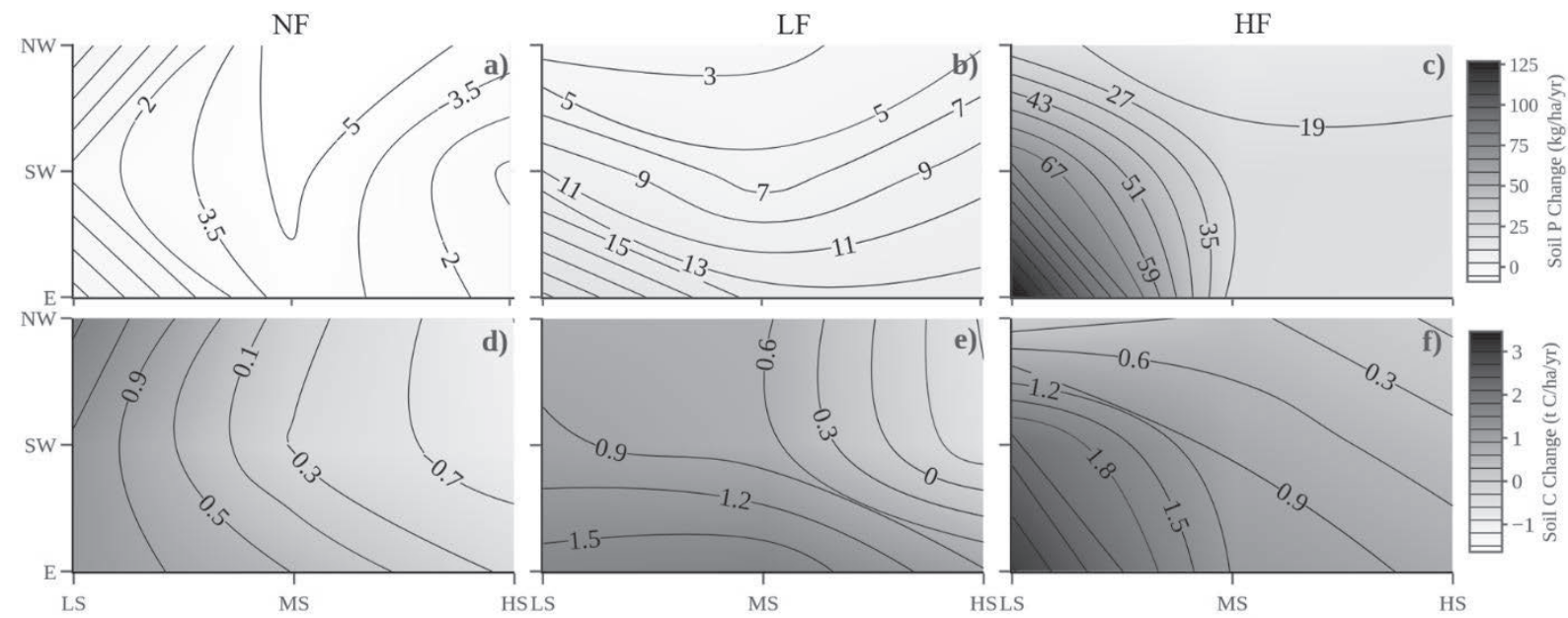

Figure 2 Modelled mean annual soil P (a, b, c) and C (d, e, f) changes across the different farmlets [NF (no SSP applied); LF (125 $\mathrm{kg} \mathrm{SSP} / \mathrm{ha} /$ year); HF (375 kg SSP/ha/year), since 1980] as affected by slope (LS = low slope, MS = medium slope, HS $=$ high slope $)$ and aspect $(E=$ east aspect, $\mathrm{SW}=$ southwest aspect, $\mathrm{NW}=$ northwest aspect) positions.

incorporated into the soil to a depth of $30 \mathrm{~cm}$.

This study was conducted using limited datasets (both limited in number and scope), so a number of assumptions had to be made when modelling soil $\mathrm{C}$, including: a) $20 \%$ of $\mathrm{C}$ from pasture intake ends up in soil (i.e. $80 \%$ of the organic matter ingested was digestible); b) assumed probabilities of pasture utilisation in different slope classes were based on grazing behaviour, with an overall assumption of $70 \%$ pasture utilisation; with c) an almost $30 \%$ of herbage mass accumulation returned to soils as litter; and d) soil and plant $\mathrm{C}$ respiration rates solved by equations (Saggar et al. 1997; Saggar et al. 1999). Further work is required to obtain additional quantitative data for, and examine the sensitivity and behaviour of, each of these variables to explore why the model predicted $\mathrm{C}$ accumulation across all three farmlets, when measured values of soil $\mathrm{C}$ stocks in the three farmlets have shown minimal change over the last 40 years, despite the large differences in $\mathrm{P}$ fertilisation and carrying capacity (Lambert et al. 2000; Mackay et al. 2018). The long-term $P$ fertiliser and sheep grazing study utilised here provides a unique field laboratory for this type of research to advance our understanding of C dynamics in hill country systems.

\section{Practical implications}

The inclusion of aspect (in addition to slope) within the model structure was valuable in spatially modelling nutrient distribution in hill country grazed by livestock. It also provides a portable basis for a sampling strategy for quantifying soil $\mathrm{C}$ stocks in highly variable hill land. However, understanding the spatial patterns of soil $\mathrm{C}$ across the farmlets is a key element in the design of any soil $\mathrm{C}$-stock monitoring regime and future changes in $\mathrm{C}$ inventories should highlight the spatial and temporal effects of topography and animal behaviour on soil $\mathrm{C}$ changes.

\section{ACKNOWLEDGEMENTS}

Model development and analysis, and preparation of the manuscript was partly funded by the Sustainable Land Management and Climate Change fund of the Ministry for Primary Industries and the AgResearch Strategic Science Investment Fund. FB was funded by the New Zealand Government through the LEARN Awards programme, and hosted by AgResearch Grasslands, Palmerston North.

\section{REFERENCES}

Coop IE. 1965. A review of the ewe equivalent system.

New Zealand Agricultural Science 1: 13-18.

Fortmann-Roe S. 2014. Insight Maker: A generalpurpose tool for web-based modeling \& simulation. Simulation Modelling Practice and Theory 47: 2845.

Hoogendoorn CJ, Bowatte S, Tillman RW. 2011. Simple models of carbon and nitrogen cycling in New Zealand hill country pastures: exploring impacts of intensification on soil $\mathrm{C}$ and $\mathrm{N}$ pools. New Zealand Journal of Agricultural Research 54: 221-249.

Lal R, Negassa W, Lorenz K. 2015. Carbon sequestration in soil. Current Opinion in Environmental Sustainability 15: 79-86.

Lambert MG, Clark DA, Grant DA, Costall DA, Fletcher RH. 1983. Influence of fertiliser and grazing management on North Island moist hill country. New Zealand Journal of Agricultural Research 26: 95108. 
Lambert MG, Clark DA, Mackay AD, Costall DA. 2000. Effects of fertiliser application on nutrient status and organic matter content of hill soils. New Zealand Journal of Agricultural Research 43: 127138.

Lambert MG, Mackay AD, Ganesh S, Upsdell MP. 2014. Responses of grazed New Zealand hill pastures to rates of superphosphate application. New Zealand Journal of Agricultural Research 57: 149-164.

Lambert MG, Roberts E. 1978. Aspect differences in an unimproved hill country pasture. II. Edaphic and biotic differences. New Zealand Journal of Agricultural Research 21: 255-260.

López IF, Hodgson J, Hedderley DI, Valentine I, Lambert MG. 2003a. Selective defoliation by sheep according to slope and plant species in the hill country of New Zealand. Grass and Forage Science 58: 339-349.

López IF, Lambert MG, Mackay AD, Valentine I. 2003b. The influence of topography and pasture management on soil characteristics and herbage accumulation in hill pasture in the North Island of New Zealand. Plant and Soil 255: 421-434.

Mackay A, Costall D. 2016. Long-term changes in soil fertility in hill country. Hill Country-Grassland Research and Practice Series 16: 157-162.

Mackay AD, Vibart R, McKenzie C. 2018. Changes in soil carbon in hill-country under contrasting phosphorus fertiliser and sheep stocking rates. Journal of New Zealand Grasslands 80: 263-268.

Parfitt RL, Mackay AD, Ross DJ, Budding PJ. 2009. Effects of soil fertility on leaching losses of N, $\mathrm{P}$ and $\mathrm{C}$ in hill country. New Zealand Journal of Agricultural Research 52: 69-80.
Saggar S, Mackay AD, Hedley MJ, Lambert MG, Clark DA. 1990. A nutrient-transfer model to explain the fate of phosphorus and sulphur in a grazed hill-country pasture. Agriculture, Ecosystems \& Environment 30: 295-315.

Saggar S, Hedley CA, Mackay A. 1997. Partitioning and translocation of photosynthetically fixed $14 \mathrm{C}$ in grazed hill pastures. Biology and Fertility of Soils 25: 152-158.

Saggar S, Mackay AD, Hedley CB. 1999. Hill slope effects on the vertical fluxes of photosynthetically fixed $14 \mathrm{C}$ in a grazed pasture. Soil Research 37: 655-666.

Saggar S, Giltrap DL, Davison R, Gibson R, de Klein CAM, Rollo M, Ettema P, Rys G. 2015. Estimating direct $\mathrm{N}_{2} \mathrm{O}$ emissions from sheep, beef, and deer grazed pastures in New Zealand hill country: accounting for the effect of land slope on the $\mathrm{N}_{2} \mathrm{O}$ emission factors from urine and dung. Agriculture, Ecosystems \& Environment 205: 70-78.

Scott DT, Baisden WT, Davies-Colley R, Gomez B, Hicks DM, Page MJ, Preston NJ, Trustrum NA, Tate KR, Woods RA. 2006. Localized erosion affects national carbon budget. Geophysical Research Letters 33.

Schipper LA, Mudge PL, Kirschbaum MUF, Hedley CB, Golubiewski NE, Smaill SJ, Kelliher FM. 2017. A review of soil carbon change in New Zealand's grazed grasslands. New Zealand Journal of Agricultural Research 60: 93-118.

Soussana J-F, Loiseau P, Vuichard N, Ceschia E, Balesdent J, Chevallier T, Arrouays D. 2004. Carbon cycling and sequestration opportunities in temperate grasslands. Soil Use and Management 20: 219-230.

Appendix 1 Parameters and equations used to calculate changes in total soil P content (30 cm depth).

\begin{tabular}{|c|c|}
\hline Parameter \& symbol & Description and equation development \\
\hline $\mathrm{PPC}_{s a}$ & $\begin{array}{l}\text { Plant P concentration per each slope }(s) \text { and aspect }(a) \text { combination } \\
\text { Olsen } \mathrm{P}<55 \mu \mathrm{g} / \mathrm{mL}, \mathrm{PPC}(\%)=-0.0001 \times 0 \text { Olsen } \mathrm{P}_{s a}{ }^{2}+ \\
0.0113 \times \text { Olsen }_{s a}+0.1069 \text { Olsen } \mathrm{P}>55 \mu \mathrm{g} / \mathrm{mL}, \mathrm{PPC}(\%)=0.43\end{array}$ \\
\hline Plant $_{\mathrm{P} \text { uptake sa }}$ & $\begin{array}{l}\text { Total plant } \mathrm{P} \text { uptake by pasture per each slope }(s) \text { and aspect }(a) \text { combination } \\
\text { Plant }_{\mathrm{P} \text { uptake } s a}(\mathrm{~kg} \mathrm{P} / \mathrm{ha} / \text { year })=\mathrm{PP}_{s a} \times \frac{\mathrm{PPC}_{s a}}{100} \times \frac{\text { Area }_{s a}}{100}\end{array}$ \\
\hline Plant $_{\mathrm{P} \text { litter sa }}$ & $\begin{array}{l}\text { Plant } \mathrm{P} \text { litter per each slope }(s) \text { and aspect }(a) \text { combination } \\
\text { Plant } \mathrm{P}_{\text {litter } s a}(\mathrm{~kg} \mathrm{P} / \text { ha/year })=\mathrm{PP}_{s a}-\text { Past }_{\mathrm{P} \text { intake } s a}\end{array}$ \\
\hline Past $_{\mathrm{P} \text { ap }}$ & $\begin{array}{l}\text { Phosphorus intake removed as animal product per each farmlet per year } \\
\text { Past } \mathrm{P}_{\mathrm{ap}}(\mathrm{kg} \mathrm{P} / \mathrm{ha} / \text { year })=\sum \text { Past }_{\text {Pintake } s a} \times \frac{15}{100}\end{array}$ \\
\hline$P_{\text {exc }}$ & $\begin{array}{l}\text { Phosphorus excreted per each farmlet per year } \\
\quad \mathrm{P}_{\text {exc }}(\mathrm{kg} \mathrm{P} / \text { ha/year })=\sum \text { Past }_{\text {Pintake } s a}-\text { Past } \mathrm{P}_{\text {rap }}\end{array}$ \\
\hline $\mathrm{TPL}_{s a}$ & $\begin{array}{l}\text { Total P losses from pastures per each slope }(s) \text { and aspect }(a) \text { combination } \\
\qquad \mathrm{TPL}_{s a}(\mathrm{~kg} \mathrm{P} / \mathrm{ha} / \text { year })=\frac{\mathrm{DRP}_{s a}}{0.15}\end{array}$ \\
\hline Olsen $\mathrm{P}_{\mathrm{vol} s a}$ & $\begin{array}{l}\text { A logistic curve for volumetric Olsen } \mathrm{P} \text { according to total soil } \mathrm{P} \text { at } 30 \mathrm{~cm} \text { depth was developed fitting a } \\
\text { regression with nonlinear adjustment by the least square method. } \\
\text { Olsen } \mathrm{P}_{\mathrm{vol} s a}(\mu \mathrm{g} / \mathrm{mL})=\frac{-110.2}{\left(1+\mathrm{EXP}\left(-4.72 .4 \times 10^{-3}\right) \times \mathrm{TSP}_{s a}\right)}+107.5 \\
\end{array}$ \\
\hline
\end{tabular}


Appendix 2 Parameters and equations used to calculate changes on total soil C content (30 cm depth).

\section{Parameter \& symbol Description and equation development}

$\mathrm{C}_{\text {shoot }}$

To calculate the aboveground $\mathrm{C}$ accumulation ( $\mathrm{C}$ shoot), it was assumed a $90 \%$ of organic matter, where a $40 \%$ was considered as C

$$
\mathrm{C}_{\text {shoot }}(\mathrm{kg} \mathrm{C} / \mathrm{ha} / \text { year })=\mathrm{PP} \times 0.9 \times 0.4
$$

\begin{tabular}{|c|c|}
\hline $\mathrm{C}_{\text {root and rhizodeposition }}$ & $\begin{array}{l}\text { To estimate the } \mathrm{C} \text { allocated to the roots and rhizodeposition, it was built a logarithmic equation representing } \\
\text { the data shown by Saggar et al. (1997); Saggar et al. (1999) } \\
\mathrm{C}_{\text {Root and Rhizodeposition }}(\mathrm{kg} \mathrm{C} / \text { ha/year })=2979.7 * \operatorname{Ln}\left(\mathrm{C}_{\text {shoot }}\right)-20084\end{array}$ \\
\hline $\mathrm{C}_{\text {intake sa }}$ & $\begin{array}{l}\text { The percentage pasture utilisation (PU) for each slope and aspect combination was utilised to estimate the } \\
\text { amount of pasture } \mathrm{C} \text { intake by the animals } \\
\qquad \mathrm{C}_{\text {intake } s a}(\mathrm{~kg} \mathrm{C} / \mathrm{ha} / \text { year })=\mathrm{PU}_{s a} \times \frac{\mathrm{C}_{\text {shoot } s a}}{100}\end{array}$ \\
\hline $\mathrm{C}_{\text {litter sa }}$ & $\begin{array}{l}\text { The plant } \mathrm{C} \text { not utilised by animals was directly returned to the soil through the plant litter and it was } \\
\text { assumed a complete incorporation into the soil } \mathrm{C} \text { pool } \\
\qquad \mathrm{C}_{\text {litter } s a}(\mathrm{~kg} \mathrm{C} / \text { ha/year })=\mathrm{PP}_{s a}-\mathrm{C}_{\text {intake }} \text { sa }\end{array}$ \\
\hline $\mathrm{C}_{\mathrm{exc}}$ & $\begin{array}{l}\text { The indigestible fraction of the herbage from the } \mathrm{C}_{\text {intake }} \text { is returned as dung to the soil } \mathrm{C} \text { pool. We assumed } \\
\text { an organic matter digestibility }(\mathrm{OMD}) \text { constant value of } 80 \% \\
\qquad \mathrm{C}_{\text {exc }}(\mathrm{kg} \mathrm{C} / \mathrm{ha} / \text { year })=\sum \mathrm{C}_{\text {intake } s a} \times\left(1-\mathrm{OMD}_{\text {sa }}\right)\end{array}$ \\
\hline $\mathrm{C}_{\mathrm{ap}}$ & $\begin{array}{l}\text { According to Soussana et al. (2004), it was assumed that } 2 \% \text { of the } \mathrm{C}_{\text {intake }} \text { was removed as animal product } \\
\qquad \mathrm{C}_{\mathrm{ap}}(\mathrm{kg} \mathrm{C} / \mathrm{ha} / \text { year })=\sum \mathrm{C}_{\text {intake } s a} \times \frac{2}{100}\end{array}$ \\
\hline $\mathrm{C}_{\text {methane }}$ & $\begin{array}{l}\text { The ratio of } \mathrm{C} \text { emitted as methane per each } \mathrm{kg} \text { of } \mathrm{DMI} \text { is around } 5 \% \text { (Soussana et al. 2004) } \\
\qquad \mathrm{C}_{\text {methane }}(\mathrm{kg} \mathrm{C} / \mathrm{ha} / \text { year })=\sum \mathrm{C}_{\text {intake }} \mathrm{sa} \times \frac{5}{100}\end{array}$ \\
\hline $\mathrm{C}_{\text {res-a }}$ & $\begin{array}{l}\text { The } \mathrm{C} \text { respired as } \mathrm{CO}_{2} \text { by the animal was calculated as the difference between the amount of } \mathrm{C}_{\text {intake }}, \mathrm{C}_{\mathrm{exc}} \\
\text { and carbon losses such as } \mathrm{C}_{\mathrm{ap}} \text { and } \mathrm{C}_{\text {methane }} \\
\qquad \begin{array}{c}\mathrm{C}_{\text {res-a }}(\mathrm{kg} \mathrm{C} / \mathrm{ha} / \text { year }) \\
\qquad=\sum \mathrm{C}_{\text {intake } s a}-\sum C_{\text {ap sa }}-\sum C_{\text {exc sa }}-\sum C_{\text {methane sa }}\end{array}\end{array}$ \\
\hline
\end{tabular}

$C_{\text {res-ps }}$

According to Saggar et al. (1997); Saggar et al. (1999), the plant and soil respiration follow an exponential behaviour related to aboveground $\mathrm{C}$ allocation $\left(\mathrm{C}_{\text {shoot }}\right)$

$\mathrm{C}_{\text {res-ps }}(\mathrm{kg} \mathrm{C} / \mathrm{ha} /$ year $)=0.0002 \times \mathrm{C}_{\text {shoot }}{ }^{2}-0.4727 \times \mathrm{C}_{\text {shoot }}+4300$

POC

The amount transported of particulate organic carbon considered by erosion of sediments into rivers and other water bodies was $53 \mathrm{~kg} \mathrm{C/ha/year} \mathrm{(Scott} \mathrm{et} \mathrm{al.} \mathrm{2006)}$

DOC

According to Parfitt et al. (2009), the C losses as dissolved organic carbon through leaching or runoff for NF, LF and HF were 121, 174 and $228 \mathrm{~kg} \mathrm{C/ha/year,} \mathrm{respectively.}$ 
